University of Nebraska - Lincoln

DigitalCommons@University of Nebraska - Lincoln

Publications, Agencies and Staff of the U.S.

Department of Commerce

U.S. Department of Commerce

$10-2008$

\title{
Acoustic Pingers Eliminate Beaked Whale Bycatch in a Gill Net Fishery
}

James Carretta

National Oceanic and Atmospheric Administration

Jay Barlow

National Oceanic and Atmospheric Administration, jay.barlow@noaa.gov

Lyle Enriquez

NOAA Fisheries, Southwest Regional Office

Follow this and additional works at: https://digitalcommons.unl.edu/usdeptcommercepub

Part of the Environmental Sciences Commons

Carretta, James; Barlow, Jay; and Enriquez, Lyle, "Acoustic Pingers Eliminate Beaked Whale Bycatch in a Gill Net Fishery" (2008). Publications, Agencies and Staff of the U.S. Department of Commerce. 47. https://digitalcommons.unl.edu/usdeptcommercepub/47

This Article is brought to you for free and open access by the U.S. Department of Commerce at DigitalCommons@University of Nebraska - Lincoln. It has been accepted for inclusion in Publications, Agencies and Staff of the U.S. Department of Commerce by an authorized administrator of DigitalCommons@University of Nebraska - Lincoln. 
MARINE MAMMAL SCIENCE, 24(4): 956-961 (October 2008)

No claim to original US government works

DOI: $10.1111 /$ j.1748-7692.2008.00218.x

Acoustic pingers eliminate beaked whale

bycatch in a gill net fishery

JAMES V. CARRETTA

JAY BARLOW

National Oceanic and Atmospheric Administration,

NOAA Fisheries Service,

Southwest Fisheries Science Center,

8604 La Jolla Shores Drive, La Jolla, California 92037, U.S.A.

E-mail: jim.carretta@noaa.gov

\section{LYLE ENRIQUEZ}

NOAA Fisheries, Southwest Regional Office, 510 West Ocean Boulevard, Long Beach, California 90802, U.S.A.

Bycatch of beaked whales in gill net fisheries has been documented worldwide (Nicholson 1954, Di Natale 1994, Read 1994, Siliciliano 1994, Julian and Beeson 1998, Waring et al. 2006). Acoustic pingers have been successfully used to reduce bycatch of harbor porpoises (Phocoena phocoena) (Kraus et al. 1997, Trippel et al. 1999, Gearin et al. 2000) and common dolphins (Delphinus delphis) (Barlow and Cameron 2003), but pinger efficacy in reducing beaked whale bycatch has never been evaluated due to the rarity of beaked whale entanglements in fisheries. We report that bycatch of beaked whales in a California drift gill net fishery dropped to zero when acoustic pingers were added to reduce cetacean bycatch and that this effect is much greater than bycatch reductions for other cetacean taxa.

Our study is based on $17 \mathrm{yr}$ of fishery observer data collected by biologists at sea aboard drift gill net vessels fishing for swordfish and sharks in the California Current (Julian and Beeson 1998, Carretta et al. 2005). In the first $6 \mathrm{yr}$ of the fishery observer program (1990-1995), biologists observed 33 beaked whales entangled in 3,303 fishing sets: 21 Cuvier's beaked whales (Ziphius cavirostris), 5 Hubb's beaked whales (Mesoplodon carlhubbsi), 1 Stejneger's beaked whale (M. stejnegeri), 1 Baird's beaked whale (Berardius bairdii), 2 unidentified Mesoplodon species, and three "unidentified ziphiids" (Fig. 1). All entanglements were single animals. Since pinger use began in 1996, there have been no beaked whale entanglements in 4,381 observed sets through 2006 (Fig. 2). In contrast, 260 cetaceans representing 12 species were observed entangled during this same 11-yr period.

The sound characteristics of pingers used in this fishery are specified in regulations (source level $\sim 135 \mathrm{~dB}$ RMS, re: $1 \mu \mathrm{Pa} @ 1 \mathrm{~m}$, frequency $10-12 \mathrm{kHz}$, pulse duration $=300 \mathrm{~ms}$, pulse interval $=4 \mathrm{~s}$ ). A simple spherical propagation model indicates that these sounds should be audible at $15 \mathrm{~dB}$ over ambient noise at $100 \mathrm{~m}$. Pinger frequencies $(10-12 \mathrm{kHz})$ are within the range of sounds $(5-80 \mathrm{kHz})$ that Cook et al. (2006) reported to be detectable by beaked whales, but are lower than 


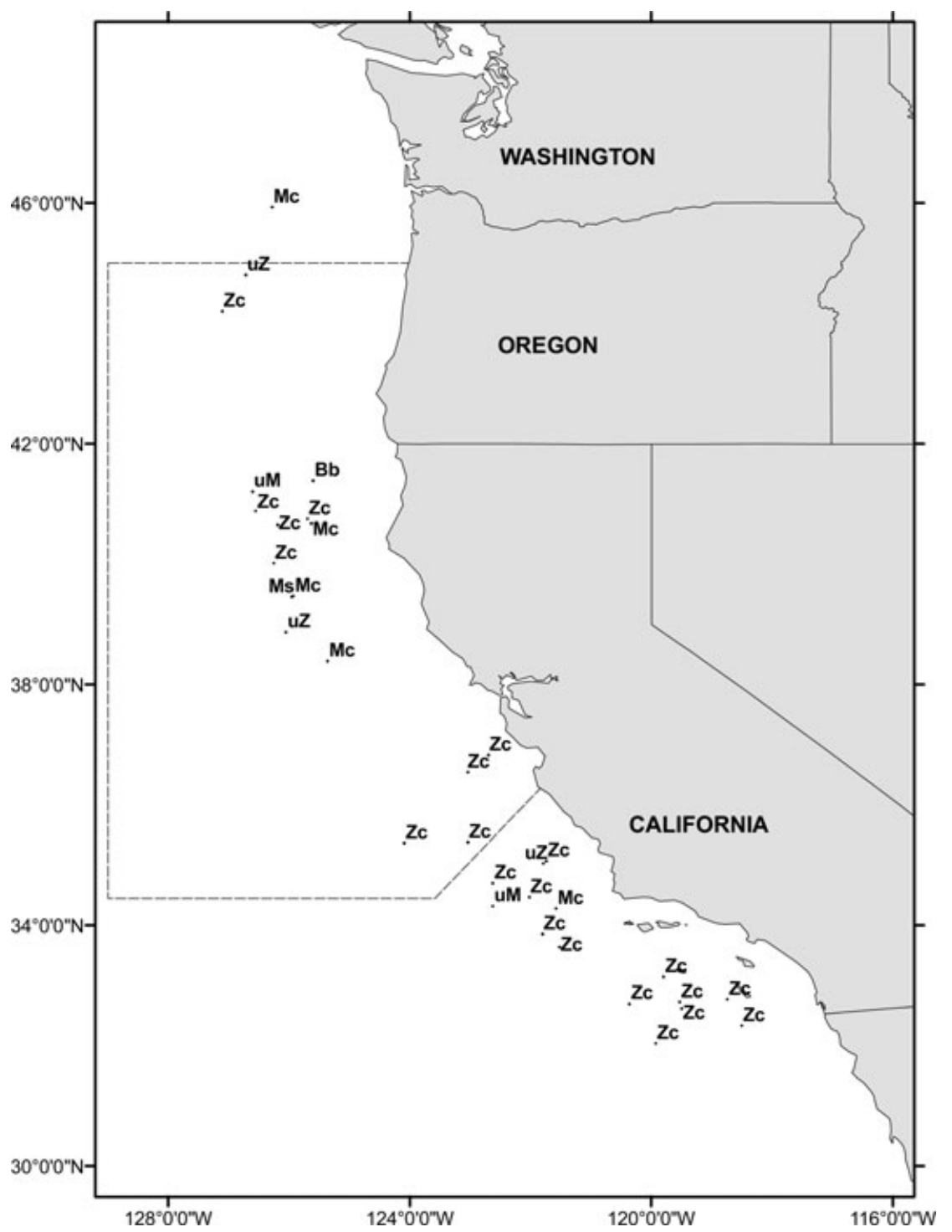

Figure 1. Locations of observed beaked whale entanglements in the swordfish drift gill net fishery. Species key: $\mathrm{Bb}=$ Berardius bairdii, $\mathrm{Mc}=$ Mesoplodon carlbubbsi, $\mathrm{Ms}=$ Mesoplodon stejnegeri, $\mathrm{Zc}=$ Ziphius cavirostris, $\mathrm{uM}=$ unidentified Mesoplodon species, $\mathrm{uZ}=$ unidentified ziphiid. Bounded region has been closed to gill netting from 15 August to 15 November annually since 2001 .

peak frequencies recorded from $Z$. cavirostris and M. densirostris (Johnson et al. 2004, Zimmer et al. 2005). Pinger frequencies do overlap with sounds recorded from $M$. densirostris near Hawaii (Rankin and Barlow 2007) and B. bairdii off the U.S. west coast (Dawson et al. 1998). Nets in this fishery are approximately $1,800 \mathrm{~m}$ long 


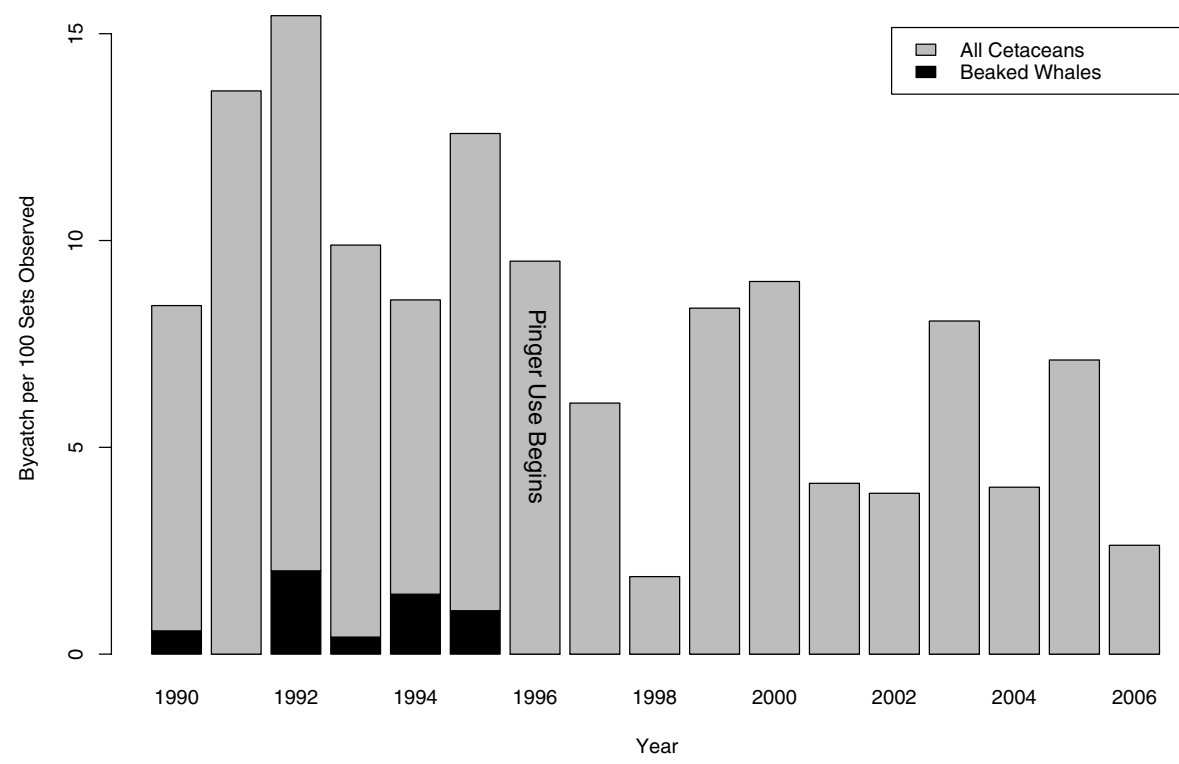

Figure 2. Bycatch rates (of individuals) of all cetaceans and beaked whales per 100 observed sets, 1990-2006.

and $65 \mathrm{~m}$ deep, with mesh sizes ranging from 35 to $60 \mathrm{~cm}$. Nets are fished from dusk until dawn and are suspended from floats so that the tops of the nets are at 11-22 $\mathrm{m}$ depth and the bottoms are at 75-90 m depth. Regulations require that acoustic pingers be attached every $91 \mathrm{~m}$ and within $9 \mathrm{~m}$ of the floatline, and every $91 \mathrm{~m}$ and within $11 \mathrm{~m}$ of the leadline. Thus, the average net contains approximately 40 pingers.

Three significant regulatory changes have occurred in this fishery since 1996: the introduction of acoustic pingers, a mandatory increase in minimum fishing depth to $11 \mathrm{~m}$, and a seasonal area closure implemented in 2001 that shifted fishing effort to the south (Fig. 3). Of these changes, the introduction of pingers is the most likely factor in the reduction of beaked whale bycatch. Minimum fishing depth requirements are not a likely factor, as most sets (63\%) were already fished $11 \mathrm{~m}$ or deeper before regulations took effect. Also, the proportion of sets fished at $<11 \mathrm{~m}$ $(37 \%)$ and the proportion of total beaked whale bycatch $(36 \%)$ observed in these "shallow" sets were nearly identical. The area closure is not a likely factor, as beaked whale entanglements had already dropped to zero in 2,670 observed sets with pingers for five consecutive years preceding the closure. Also, the rate of beaked whale entanglements inside the closure area (17 whales in 1,410 sets) and outside the closure area (16 whales in 1,893 sets) did not differ significantly from 1990 to 1995 $(P=0.34$, two-tailed randomization test).

A decline in beaked whale entanglements might be expected from an overall decline in beaked whale abundance in the California Current. The combined abundance of Ziphius, Mesoplodon sp. (most sightings of Mesoplodon could only be identified 

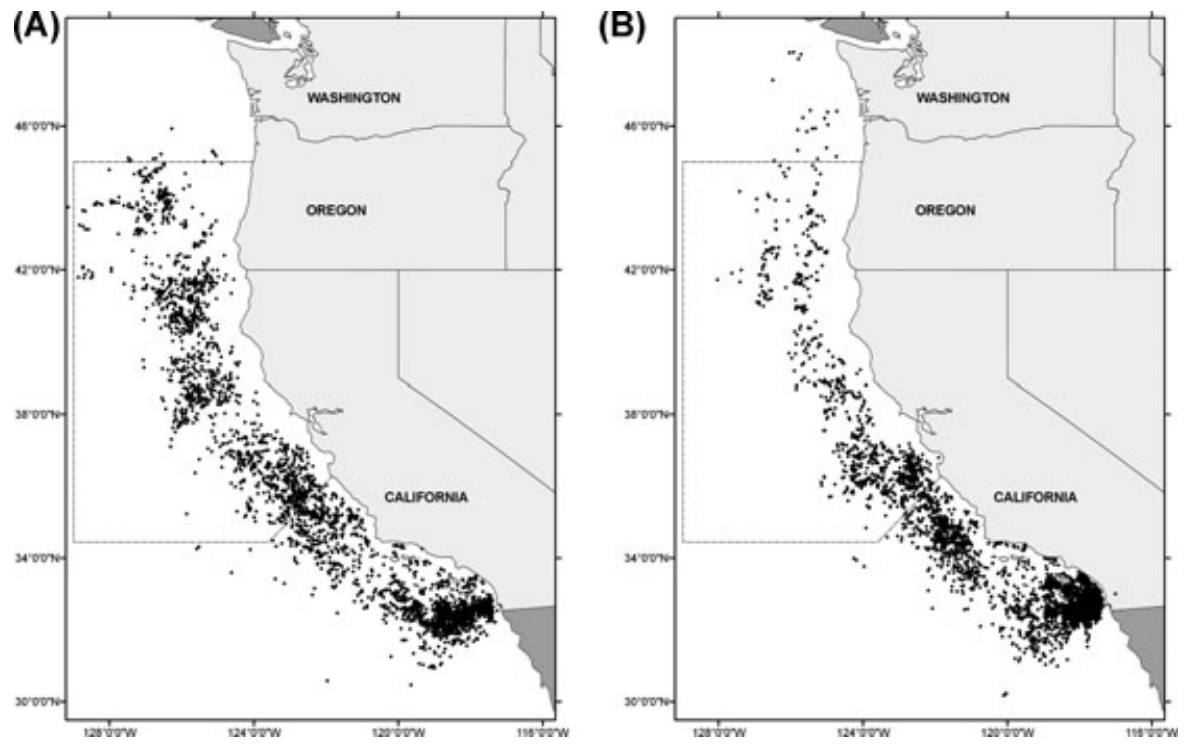

Figure 3. Location of observed fishing sets in the swordfish drift gill net fishery during 1990-1995 (A) and 1996-2006 (B). Bounded region has been closed to gill netting from 15 August to 15 November annually since 2001.

to genus), and Berardius in the California Current has been estimated at approximately 7,000 whales for the period 1991-2005, which exceeds combined estimates of blue, fin, and humpback whale abundance in the same region (Barlow and Forney 2007). Survey-specific estimates of beaked whale abundance declined by $62 \%$ over this period, but some of that apparent decline is attributed to rougher weather during later surveys. Taylor et al. (2007) showed that the probability of detecting a precipitous decline in beaked whale abundance is quite low, given the low precision of survey estimates (CVs $>0.60)$ and intervals between surveys ( $4 \mathrm{yr}$ ). Given the relative rarity of beaked whale sightings, we are unable to determine if the observed decline is statistically significant. Another measure of relative beaked whale abundance is the number of stranded animals. Thirty beaked whale strandings were reported to the California Marine Mammal Stranding Network between 1990 and 2006 and the mean number of annual strandings increased slightly following pinger use (1.66 in years without pingers and 1.82 with pingers).

To evaluate whether the observed absence of beaked whale entanglements during the last $11 \mathrm{yr}$ could have resulted by chance, we examined the probability of observing zero entanglements in 4,381 sets with a simple Poisson model, using the observed entanglement rate prior to pinger use (33 entanglements 3,303 sets $=0.00999$ entanglements per set). Given this entanglement rate, the expected number of observed entanglements in 4,381 sets is 43.77 and the Poisson probability of observing zero entanglements is $<10^{-19}$. The likelihood of observing zero entanglements remains low even if the beaked whale population and expected number of entanglements have decreased by $62 \%\left(P=10^{-7}\right)$ or even by $90 \%(P=0.013)$. The likelihood 
that beaked whale abundance has declined in this region by more than $90 \%$ seems remote, given recent abundance estimates and stranding records. The difference in beaked whale entanglement rates with and without pingers is so large that it cannot be explained as a sampling artifact. In contrast, bycatch rates of all cetaceans (mostly dolphins) decreased by only $50 \%$ over the same period. Continued bycatch of other cetacean species in the absence of beaked whale bycatch suggests that beaked whales may be among the most sensitive of the cetacean taxa to sounds within the frequency range produced by pingers. These results contribute to our understanding of beaked whale sensitivity to anthropogenic sound and highlight recent concerns about potential threats that some sound sources may pose to beaked whales (Simmonds and Lopez-Jurando 1991, Frantzis 1998, Balcomb and Claridge 2001, Jepson et al. 2003, Aguilar de Soto et al. 2006, Barlow and Gisiner 2006, Cox et al. 2006).

\section{ACKNOWLEDGMENTS}

We thank M. McDonald, A. Milligan, T. Eguchi, R. Pitman, J. Rusin, K. Allen, N. Bartoo, S. Chivers, J. Larese, and P. Olson for reviewing the manuscript. This work would not have been possible without the support of the NOAA Fisheries Southwest Regional Office observer program and the cooperation of the drift gillnet fishermen.

\section{Literature Cited}

Aguilar de Soto, N. A., M. Johnson, P. T. Madsen, P. L. Tyack, A. Bocconcelli AND J. FABRIZIO BORSANI. 2006. Does intense ship noise disrupt foraging in deepdiving Cuvier's beaked whales (Ziphius cavirostris)? Marine Mammal Science 22:690699.

Balcomb, K. C. III, And D. E. Claridge. 2001. A mass stranding of cetaceans caused by naval sonar in the Bahamas. Bahamas Journal of Science 2:2-12.

BARlow, J., AND G. A. CAMERON. 2003. Field experiments show that acoustic pingers reduce marine mammal bycatch in the California drift gillnet fishery. Marine Mammal Science 19:265-283.

Barlow J., AND K. A. Forney. 2007. Abundance and density of cetaceans in the California Current ecosystem. Fishery Bulletin 105:509-526.

BARLOW, J., AND R. Gisiner. 2006. Mitigating, monitoring, and assessing the effects of anthropogenic sound on beaked whales. Journal of Cetacean Research and Management 7:239-249.

Carretta, J. V., T. Price, D. Petersen and R. Read. 2005. Estimates of marine mammal, sea turtle, and seabird mortality in the California drift gillnet fishery for swordfish and thresher shark, 1996-2002. Marine Fisheries Review 66(2):21-30.

Cook, M. L. H., R. A. Varela, J. D. Goldstein, S. D. McCulloch, G. D. Bossart, J. J. FinNERAN, D. Houser AND D. A. MANN. 2006. Beaked whale auditory evoked potential hearing measurements. Journal of Comparative Physiology A 192:489-495.

Cox, T. M., T. J. Ragen, A. J. Read, E. Vos, R. W. Baird, K. Balcomb, J. Barlow, J. Caldwell, T. Cranford, L. Crum, A. D'Amico, G. D'Spain, A. Fernandez, J. Finneran, R. Gentry, W. Gerth, F. Gulland, J. Hildebrand, D. Houser, T. Hullar, P. D. Jepson, D. Ketten, C. D. Macleod, P. Miller, S. Moore, D. C. Mountain, D. Palka, P. Ponganis, S. Rommel, T. Rowles, B. Taylor, P. Tyack, D. Wartzok, R. GISINER, J. MEAD AND L. BENNER. 2006. Understanding the impacts of anthropogenic sound on beaked whales. Journal of Cetacean Research and Management 7:177-187.

Dawson, S., J. BARlow and D. LJungblad. 1998. Sounds recorded from Baird's beaked whale, Berardius bairdii. Marine Mammal Science 14:335-344. 
Di NATALE, A. 1994. A review of passive fishing nets and trap fisheries in the Mediterranean Sea and of the cetacean bycatch. Report of the International Whaling Commission. (Special Issue 15):189-202.

FrantZIS, A. 1998. Does acoustic testing strand whales? Nature 392:29.

Gearin, P. J., M. E. Gosho, J. L. LaAke, L. Cooke, R. L. Delong and K. M. Hughes. 2000. Experimental testing of acoustic alarms (pingers) to reduce bycatch of harbour porpoise, Phocoena phocoena, in the state of Washington. Journal of Cetacean Research and Management 2:1-9.

Jepson, P. D., M. Arbelo, R. Deaville, I. A. P. Patterson, P. Castro, J. R. Baker, E. Degollada, H. M. Ross, P. Herráez, A. M. Pocknell, F. Rodriguez, F. E. Howie, A. Espinosa, R. J. Reid, J. R. Jaber, V. Martin, A. A. Cunningham and A. Fernandez. 2003. Gas-bubble lesions in stranded cetaceans. Nature 425:575-576.

Johnson, M., P. T. Madsen, W. M. X. Zimmer, N. A. De Soto and P. L. Tyack. 2004. Beaked whales echolocate on prey. Proceedings of The Royal Society of London B 271:S383-S386.

JULIAN, F., AND M. BEESON. 1998. Estimates of marine mammal, turtle, and seabird mortality for two California gillnet fisheries: 1990-1995. Fishery Bulletin 96:271-284.

Kraus, S. D., A. J. Read, A. Solow, K. Baldwin, T. Spradlin, E. Anderson and J. Williamson. 1997. Acoustic alarms reduce porpoise mortality. Nature 388:525.

Nicholson, A. J. 1954. Food of a beaked whale. Journal of Mammalogy 35:124.

RANKIN, S., AND J. BARLOW. 2007. Sounds recorded in the presence of Blainville's beaked whales, Mesoplodon densirostris, near Hawai'i. Journal Acoustical Society of America 122:42-45.

READ, A. 1994. Interactions between cetacean and gillnet and trap fisheries in the Northwest Atlantic. Report of the International Whaling Commission (Special Issue 15):133-147.

Siliciliano, S. 1994. Review of small cetaceans and fishery interactions in coastal waters of Brazil. Report of the International Whaling Commission (Special Issue 15):241-250.

SimmONDS, M. P., AND L. F. LOPEZ-JuRANDO. 1991. Whales and the military. Nature 351:448.

Taylor, B. L., M. Martinez, T. Gerrodette, J. Barlow and Y. N. Hrovat. 2007. Lessons from monitoring trends in abundance of marine mammals. Marine Mammal Science 23:157-175.

Trippel, E. A., M. B. Strong, J. M. Terhune and J. D. Conway. 1999. Mitigation of harbour porpoise (Phocoena phocoena) by-catch in the gillnet fishery in the lower Bay of Fundy. Canadian Journal of Fisheries and Aquatic Science 56:113-123.

Waring, G. T., E. Josephson, C. P. Fairfield and K. Maze-Foley. 2006. U.S. Atlantic and Gulf of Mexico marine mammal stock assessments: 2006. U.S. Department of Commerce, NOAA Technical Memorandum, NMFS-F/NE-201. 378 pp.

Zimmer, W. M. X., M. P. Johnson, P. T. MADSEN AND P. L. TYACK. 2005. Echolocation clicks of free-ranging Cuvier's beaked whales (Ziphius cavirostris). Journal of the Acoustical Society of America 117:3919-3927. 